\title{
LEARNED SOCIETIES AS PUBLISHERS
}

T HE Scientific Publications Council met at the Ciba Foundation, London, on December 13, to discuss the "Publication of Journals by Scientific Societies" with Prof. A. S. Parkes (Physiological Laboratory, Cambridge) in the chair. Dr. P. N. Campbell (Courtauld Institute of Biochemistry, London) introduced the subject with which he had been much concerned in so far as it affects the Biochemical Socioty. Societies exist to advance their respective sciences; since publication is one of the chief means to this end, the production of a journal may be regarded as a most important activity for a scientific society, which must adopt a strict editorial policy to set is standard in the field.

Old-established journals produced by commercial publishers generally adopt the same high standards, but as publication in science grows more profitable, the proliferation of specialized journals leads not only to the fragmentation of science, but also to higher costs to subscribers and, in some instances, to lowering of editorial standards.

Societios can be associated with journals in one of three ways.

In the first arrangement the society owns and publishes the journal itself. This ensures it complete control, the greatest financial benefit and, provided the society is large enough (for example, the Chomical Society), it seems the most desirable scheme.

Secondly, the society may own the journal, but employ a publisher. This arrangement is adopted by many smaller societies with no permanent editorial staff, often to secure financial backing when starting a new journal. The publisher prints, promotes, sells and distributes the journal for a commission. The Cambridge University Press does this for a number of societies, treating all exactly alike on a pro rata basis. It does an excellont and reliablo job of printing at low cost; but the commission charged for its publishing activities, Dr. Campbell considered, is high. However, if a society has no professional staff, such liaison with a publisher may be a reasonable compromise.

Thirdly, the journal may be ownod by a publisher though the society appoints the editors. The society runs no financial risk, but it also stands to gain least if the journal succeeds, so that this arrangement is rather unsatisfactory. However, a society wishing to operate in this way might do well to consider the Company of Biologists, a non-profit-making organization which owns and publishes several journals on this basis.

What can be done to help scientific societies regain the initiative?

Dr. Campbell thought that responsible scientists should he urged to consider carefully before accepting requests to serve as honorary editors of a new commercial journal. The time had come, he proposed, for societies to collaborate, taking advantage of the best commercial methods, in the production, promotion and distribution of their journals. A source of funds is required to tide societies over the early stages of publication; also advice is needed on printing and distribution costs, and accommodation must be found for editorial offices. A joint distributing organization should be created to enable societies to collaborate over subscriptions and the storage and despatch of their journals; the same organization might undertake promotion of sales.

In reply to a quostion, Dr. Campbell said that ho advocated increasing the size of existing journals rather than a multiplicity of small journals published on science, although, as Dr. T. R. E. Southwood (Imperial College of Science and Technology, London) suggested, societies start new journals not only to cover new fields but also because the editors of existing publications have noither time nor space for expansion. The quostion of sales promotion restrains many societies from severing their connexion with publishers, since large institutional sales are noeded to subsidize tho froe distribution of journals to societies' members.

Mr. A. L. Bacharach (British Journal of Nutrition) perceived tho horns of a dilemma: one could support small specialist journals, intelligible and interesting throughout, which, bocause of their small circulations, are expensive; or one could support large unspecialized journals, which are to a considerable oxtent unintelligible and costly in time to read selectively.

Dr. D. Richter (Medical Research Council Nouropsychiatric Unit. Carshalton) thought national journals are tending to give way to international periodicals with world-wide circulations such as can best be provided by the great publishing houses.

Mr. Donn Casey (Reproduction Rosearch Information Service) described his experiencos in starting the Bibliography of Reproduction, a new title-list with fourteen issues annually of eighty pages oach. $\mathrm{He}$ is compiling, promoting and distributing this with the aid of one fulltime assistant with some part-time help. It is printed by lithography, the plates for which are prepared in the office with an I.B.M. typewriter, no photographic process boing used. The quality is quite good, while the process is fast. and costs a fraction of normal type-setting.

Mr. R. W. David (Cambridge University Press) said that he hoped he could speak with uncommercial impar. tiality, although this did not mean that the Cambridge. University Press was not as compotitive and efficient as any commercial publisher. A society should first satisfy itself that its publisher is really nocessary. The publisher provides $(a)$ finance and $(b)$ a distribution service. The former is much easier than many societies believe; it is financial assistance at the early stages that is so valuable. Once a journal is established the subseriptions come in before the bills have to be paid. Through his distribution facilities, a publisher can promote sales to a marginal public; but a specialist journal for a well-defined clientele might need no publisher at all. The publisher's commission normally covers promotion, warehousing and distributing costs. However, as Dr. H. J. Rogers (National Institute for Medical Research, Mill Hill) pointed out, a society undertaking these tasks for itself would not necessarily realize the whole of the publisher's commission, for it would not only lose the benefit of the university press, whose printing costs are low, but it might also have to employ oxtra staff.

Dr. A. C. Stickland (Institute of Physics and the Physical Society) said that many printers and binders will distribute journals directly. Mr. J. C. Graddon (Royal Society) agreed, adding that the Royal Society now pub. lishes by itself and employs a firm of packers and dis. tributors. Many Follows have waived their right to copies: of all the Society's publications in favour of receiving, on request, free reprints of particular papers that interest them. Dr. Campbell's scheme was reminiscent of the science centre proposals for collaboration betweon the societies in shared premises, with their own publishing house and printer in the basement.

Dr. W. R. S. Garton (Imperial Colloge of Scionce and Technology, London) emphasized the distinction betwoon reputable publishers and a loss-scrupulous minority that act as entrepreneurs -it is the latter that start most of the new journals in order to 'sell' science as a commodity. It. is wishful thinking to suppose that in the absence of a genuine need such journals would fail for lack of support: librarians dare not ignore them. A puzzling foature is the list 
of illustrious names on the titulary boards of these journals-names that not even death can always delete from the roll, as Dr. R. K. Callow (National Institute for Medical Research, Mill Hill) interjectod. New journals should in general only be supported if they bear the imprint of a society. Mr. A. V. S. de Rouck (Ciba Foundation, London) remarked that if economic selection did not eliminate poor journals, perhaps some way should be found whereby journals could be reviewed like books and some machinery for explicit selection set up for the benefit of librarians. Mr. J. A. Rivers (J. and A. Churchill, Ltd., London) repliod that reviews may sell good books but they do not necessarily condemn bad ones, and he doubted whether they would be effective with poriodicals. While they are profitable, new journals will continue to arise, Dr. Rogers believed, and it would be a tragic mistako for sciontific socioties to lower thoir standards in order to compete with the less-desirable of those. The socioties must set the standards for all, including the commercial publishers.
A. V. S. DE REUCK

\title{
THE TEACHING OF BIOLOGY
}

\author{
By Prof. D. G. CATCHESIDE, F.R.S. \\ Department of Microbiology, University of Birmingham
}

$\mathrm{T}$ HERE is at present much discussion concerning the reform of biological teaching. The reasons are varied. There are impressions that university entrants in biology are poorer than formerly and worse prepared for the study of their subject, so biology must be made more attractive for brighter pupils. There are all the newer studies for which space must somehow be made, giving rise to questions as to which of the older material, if any, is fundamental and what relative adjustments could be made. There is the recognition that very much in the living world is common to plants and animals and microorganisms, and that therefore the cleavage into botany and zoology, as well as the separation from medicine and agriculture, goes deeper, far deeper, than it should. This is especially true of the structure and function of cells, studied by the methods of physiology, biochemistry and genetics. However, the common ground extends well beyond cell biology, and it is possible to write truly biological curricula which, with quite minor changes, may be studied with reference to either plants or animals, or to a combination of the two or, even, to a very considerable extent, with micro-organisms only. As well as tho immense growth of biochemistry, there is an important new field of biophysics to take into account. The less important, though more obvious, aspect of this concerns the specialized machines with which modern physics has supplemented the microscope; the more important aspect is the way in which individual physicists, shying from the anonymity of teams grouped around huge machines, are bringing physical ways of thought to bear on biological problems.

There are therefore several adjustments required in biological education, without further delay, partly to prevent continued fragmentation of biology, partly so that biologists may understand the newer biochemical and biophysical knowledge which is sweeping their subject, and partly so that biochemists and biophysicists may be given a broad and fundamental view of biology. Only in this way is there a chance of making the spectrum of biological knowledge continuous. No one person can hope to encompass the whole in any detail. Most will be specialists in some fairly narrow range, though a few may absorb to differing extents in several rogions.

The solution to teaching at university-level lies in the devising of new curricula which are not mere chimeras of existing courses, for biology is not merely a mixture or synthesis of zoology and botany. The courses should permit a biology student to specialize to a greater or lesser extent and attain an honours standard in three years from entry into a university. The specialisms possible may bo expected to be more varied than at present, recognizing that none can properly cover the whole of botany or of zoology. Indeed, what university course really does so even at the present time? The first year of a biology student should include a general course in biology and a general course in physical sciences; between them these should provide the whole of the specialist or vocational study.

Most authorities seem to agree that more understanding of the principles of physical sciences is needed by most biologists. It is fairly easy to see what these should be, and there is a reasonable prospect that physicists and chemists will be sufficiently interested to plan educative courses which will achieve the main objectives. These should be to fit tho developing biologist with an understanding of the principles of the physical sciences, especially in the context of their relevance to biological systems. The significant topics, several of which are not exclusively chemical or physical, ought to include:

(1) Elementary particles and atomic structure, isotopes and their application to biology.

(2) Dynamics, mass and gravity; the biological effects and applications of high and low gravity.

(3) Chemistry of inorganic and organic substances, with special reference to those of biological importance.

(4) Macromolecules.

(5) Rates of reaction, catalysis and the propertios of membranes.

(6) Electricity, light and other radiations; biological applications, for example, X-ray crystallography.

(7) Thermodynamics; work in biological systems; high. onergy bonds.

(8) Stellar and planetary evolution.

(9) Earth sciences, climatology and metoorology.

The general course in biology, which should be suitable also for biochemists and biophysicists, must be planned to give a perspective of the subject, both as regards the different levels of integration which it has and which cut right across the division into plants and animsls and. indeed, micro-organisms, and the relationship of these levels to one another. Broadly, the topics may be arranged in the following way:

(1) The cell as the basic unit of organisms, its constituont materials and their acquisition and its metabolism. Emphasis needs to be placed on the general similarity in constituent compounds and processes, on the means of energy transport and utilization, and the control of metabolic processes.

(2) The organization of cells to form tissues and moreor-less complexly differentiated organisms, with the consequent problems of procurement and processing of materials and the organization and integration of functions.

(3) Reproduction, ranging from the cellular anci subcellular levels to the organismic and dealing with chromo. some theory, the structure and function of genes and the problems of development and differentiation.

(4) Evolution, including the elementary processes of change in heredity, the evolution of adaptation, the nature of genetic systems and the consequences of these for variation and the supposed nature of species and speciation. 